\title{
Experimental verification of a very low crosstalk wavelength router construction using arrayed-waveguide grating multi/demultiplexers
}

Liu, Fenghai; Pedersen, Rune Johan Skullerud; Peucheret, Christophe; Jeppesen, Palle

Published in:

Digest of IEEE/LEOS Summer Topical Meetings 1999

Link to article, DOI:

10.1109/LEOSST.1999.794658

Publication date:

1999

Document Version

Publisher's PDF, also known as Version of record

Link back to DTU Orbit

Citation $(A P A)$ :

Liu, F., Pedersen, R. J. S., Peucheret, C., \& Jeppesen, P. (1999). Experimental verification of a very low crosstalk wavelength router construction using arrayed-waveguide grating multi/demultiplexers. In Digest of IEEE/LEOS Summer Topical Meetings 1999 (pp. 33-34). IEEE. https://doi.org/10.1109/LEOSST.1999.794658

\section{General rights}

Copyright and moral rights for the publications made accessible in the public portal are retained by the authors and/or other copyright owners and it is a condition of accessing publications that users recognise and abide by the legal requirements associated with these rights.

- Users may download and print one copy of any publication from the public portal for the purpose of private study or research.

- You may not further distribute the material or use it for any profit-making activity or commercial gain

- You may freely distribute the URL identifying the publication in the public portal 
TuA1.3

\title{
9:30 am - 9:50 am \\ Experimental verification of a very low crosstalk wavelength router construction using arrayed- waveguide grating multi/demultiplexers
}

\author{
Fenghai Liu, Rune J.S. Pedersen, Christophe Peucheret and Palle Jeppesen \\ Research Center COM, Technical University of Denmark, \\ Building 349, Lyngby DK-2800, Denmark, Email: If@com.dtu.dk
}

\begin{abstract}
Introduction: Dense Wavelength Division Multiplexing (DWDM) technology not only offers a flexible way to increase the transmission capacity, but also provides a new dimension for optical networking. Wavelength routing is very promising in future DWDM networks because of its simple structure and high degree of wavelength reuse among the nodes[1]. As the key elements in wavelength routing networks, various kinds of wavelength routers have been investigated $[2,3,4]$.
\end{abstract}

Interferometric crosstalk, i.e., crosstalk with the same wavelength as the signal, is a critical issue when implementing wavelength routing networks because the crosstalk will accumulate from all the input ports and also accumulate when the channel passes through a cascade of wavelength routers. This kind of crosstalk cannot be filtered at the receiver, and its influence has been thoroughly studied[5,6]. As an example, if the full connectivity is used in a $32 \times 32$ wavelength router, the crosstalk level from each input port must be reduced to less than $-40 \mathrm{~dB}$ in order to meet the common $1 \mathrm{~dB}$ power penalty criteria $[5,6]$. This crosstalk requirement is far from being met even by the best published results of $32 \times 32$ arrayed waveguide grating (AWG) wavelength router[4].

Although a significant amount of effort is put into reducing the crosstalk level in the AWG components[7,8,9], it is important to consider alternative structures with the same functionality as a wavelength router. In this letter, we clarify that very large $(64 \times 64) \mathrm{N} \times \mathrm{N}$ wavelength routers can be constructed so that they are not limited by interferometric crosstalk. Compared to the N $\times N$ AWG wavelength router a substantial crosstalk reduction is obtained in a $N \times N$ wavelength router structure based on $1 \times N$ AWG multi/demultiplexers due to double filtering. We demonstrate a very low crosstalk level of $-53 \mathrm{~dB}$ for such an $8 \times 8$ wavelength router based on commercially available $1 \times 8$ AWG multi/demultiplexers.

Construction: Figure 1 shows the structure of an $8 \times 8$ wavelength router using 8 pairs of $1 \times 8$ multi/demultiplexers interconnected according to the connection table of a wavelength router[1]. The wavelength channels are first demultiplexed from the input ports using AWG demultiplexers. The demultiplexed channels contain crosstalk from adjacent channels according to the transfer function of the demultiplexers. The adjacent channel crosstalk turns into interferometric crosstalk in channels with same nominal wavelength when these channels are combined in the multiplexers. However, due to the combined transfer function of the AWG demultiplexer and multiplexer, the adjacent channel crosstalk is filtered twice before resulting in interferometric crosstalk at the output ports. Such a good crosstalk suppression cannot be realized in a single component AWG wavelength router.

The number of $1 \times \mathrm{N}$ AWG multi/demultiplexers needed to build an $N \times N$ wavelength router is $2 \mathrm{~N}$, and hence scales linearly with the size of the router. The loss of $1 \times \mathrm{N}$ AWG multi/demultiplexers can be as low as $2.5 \mathrm{~dB}$ [4]. So even though the proposed construction includes the loss of an AWG multi/demultiplexer pair, the total loss is still low. The crosstalk level is significantly decreased at the same time due to the double filtering.

Characterization: In order to verify the expected crosstalk performance from the double filtering in the new wavelength router structure, an $8 \times 8$ wavelength router is constructed using commercial $1 \times 8$ AWG multi/demultiplexers with $200 \mathrm{GHz}$ wavelength channel spacing as shown in Figure 1.

Experiments have been made to identify the crosstalk induced power penalty in the $8 \times 8$ wavelength router Figure 2 shows the experimental setup. 8 lasers with a wavelength spacing of $200 \mathrm{GHz}$ are combined together after polarization alignment. The combined wavelength channels are modulated at $10 \mathrm{~Gb} / \mathrm{s}$ in a Mach-Zehnder modulator. 2 EDFAs are used before and after the modulator. The combined wavelength signal passes through a pair of interconnected $1 \times 8$ multi/demultiplexer with fiber delay lines in between; this setup simulates the crosstalk influence from the proposed $8 \times 8$ wavelength router. All channels are demultiplexed again at the receiver end. Bit error rate (BER) versus received power has been measured for each channel with and without the $1 \times 8$ multi/demultiplexer pair and is shown in Figure 3. From Figure 3, we can find that the penalty introduced by the $8 \times 8$ wavelength router for each channel is less than $0.1 \mathrm{~dB}$ at $\mathrm{BER}=10^{-9}$ and the maximum variation of sensitivity for all cases is within $0.3 \mathrm{~dB}$ at $\mathrm{BER}=10^{-9}$. This shows that the crosstalk induced penalty in the proposed $8 \times 8$ wavelength router is negligible.

We have measured the transfer functions of the $8 \times 8$ wavelength router from input ports $I 1, \mathrm{I} 2, \ldots, \mathrm{I} 8$ to output port $\mathrm{O} 1$ using a scanning wavelength laser source. From the measured transfer functions shown in Figure 4 , a loss smaller than $4.5 \mathrm{~dB}$ can be found for all channels and the crosstalk suppression is better than $53 \mathrm{~dB}$ for all channels. This confirms the low power penalty from the router.

Discussion: The measured crosstalk level in the $8 \times 8$ wavelength router shows that in this configuration, connectivity is no longer limited by crosstalk and actually a 
cascade of 40 routers would be tolerable[6]. In terms of large routers, $1 \times 64$ AWG multi/demultiplexer with crosstalk less than $-27 \mathrm{~dB}$ has been reported[4], which can be used for a $64 \times 64$ wavelength router construction. Even in this case, a cascade of 10 such routers would be possible[6]. Hence, rather large wavelength routing networks can be built using this kind of wavelength router construction.

As mentioned, the number of $1 \times \mathrm{N}$ multi/demultiplexers needed to construct a $\mathrm{N} \times \mathrm{N}$ wavelength router increases linearly with the number of ports as $2 \mathrm{~N}$. However, the relaxed requirements and the fabrication of multi/demultiplexers rather than routers will both contribute to a low cost per device.

Conclusion: A very low crosstalk $N \times N$ wavelength router construction based on $1 \times N$ AWG multi/demultiplexers has been proposed. The peak crosstalk level of $-53 \mathrm{~dB}$ is measured in such an $8 \times 8$ wavelength router and power penalty from the router is negligible. Rather large wavelength routing networks can be built using the wavelength router construction presented here.

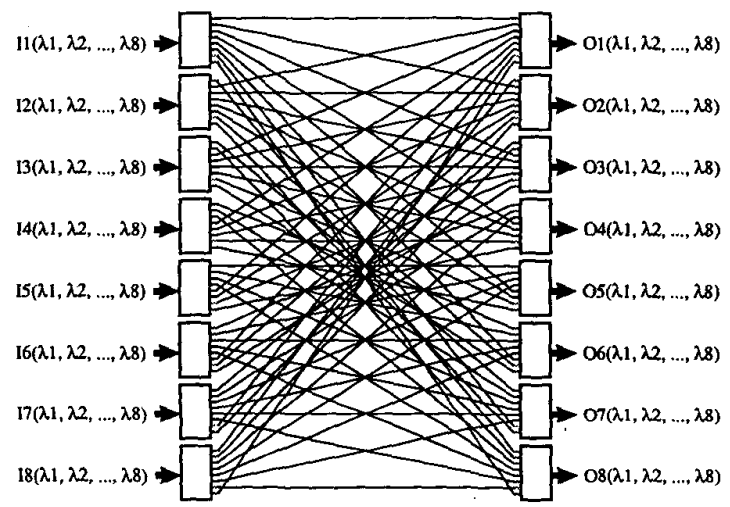

Figure 1. Structure of an $8 \times 8$ wavelength route

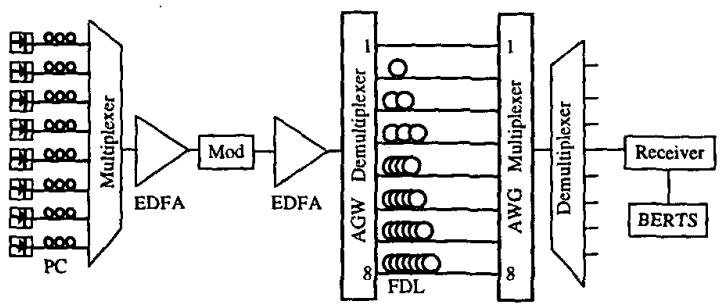

Figure 2. Experimental setup for crosstalk induced penalty measurement in the $8 \times 8$ wavelength router.

PC: polarization controller. Mod: modulator. FDL: fiber delay lines. BERTS: bit error rate test set.

\section{References}

[1] Brackett, C.A., IEEE J. Sel. Areas Commun., 1990,8, pp.948-964.

[2] Hemenway, B.R., et al, Technical Digest of Conference on Optical Fiber Communications, 1997 , PD26.

[3] Bainbridge, J.D., et al., Electron. Lett., 1997, 33, pp. 1458-1459.

[4] Okamoto, K., et al., IEICE Trans. Electron., 1998, E81C, pp. 1176-1186.

[5] Takahashi, H., et al., J. Lightwave Technol., 1996, 14,(6), pp. 1097-1105.

[6] Liu, F., Rasmussen, C.J., and Pedersen, R.J.S., Conference on Lasers and Electro-Optics, 1998, pp. 318-319.

[7] Yamada, H., et al., Electron. Lett., 1996, 33, pp. 15801582.

[8] Yamada, H., et al., Electron. Lett., 1997, 33, pp. 1608 1609.

[9] Okamoto, K., et al., Dig. Conf. Opt. Fiber Commun., 1999, pp190-192.

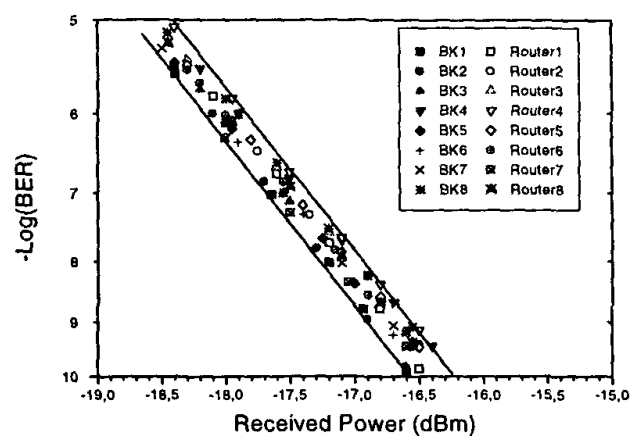

Figure 3. BER vs. Received power with/without the $8 \times 8$ wavelength router.

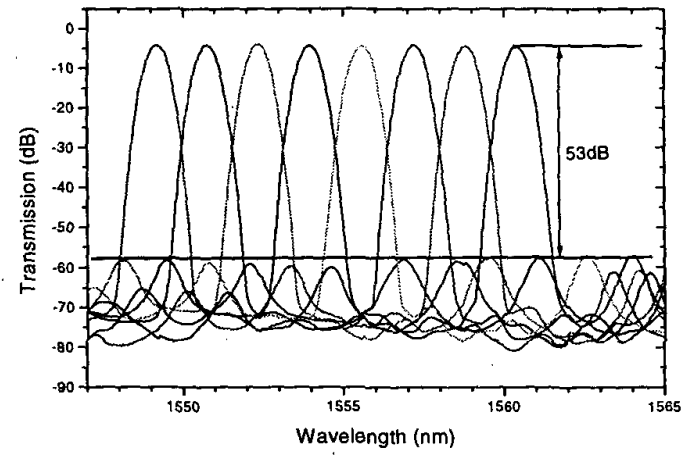

Figure 4. Transfer functions of the $8 \times 8$ wavelength router. 